\title{
港内係留船舶の長周期動摇に関する現地観測 と動摇シミュレーションの入力条件の評価 FIELD OBSERVATION ON LONG-PERIOD MOTIONS OF MOORED VESSEL AND ITS NUMERICAL SIMULATION
}

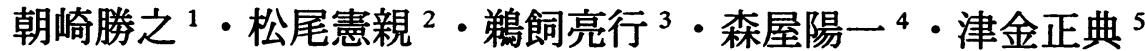 \\ Katsuyuki ASAZAKI, Norichika MATSUO, Akiyuki UKAI, Yoichi MORIYA \\ and Masanori TSUGANE \\ ${ }^{1}$ 正会員 九州電力（株）鹿児島支店（广890-8558 鹿児島県鹿児島市与次郎 2-6-16） \\ ${ }^{2}$ 工修 九州電力（株）苓北発電所建設所（广863-2504 熊本県天草郡苓北町年柄字苓陽 1091） \\ ${ }^{3}$ 正会員 工修 五洋建設（株）四国支店（T790-0011 愛媛県松山市千船町 4-4-3） \\ ${ }^{4}$ 正会員 博(工) 五洋建設（株）技術研究所（T329-2746 栃木県那須郡西那須野町四区町 1534-1） \\ ${ }^{5}$ 正会員（株）日本海洋科学（于140-0004 東京都品川区南品川 2-3-6 第 7 小池ビル 3F）
}

\begin{abstract}
Field observation on wave, current and long-period motions of a moored vessel at Reihoku Port was conducted. Highly accurate data of six motions around the center of gravity of the vessel, the tension of the mooring ropes and the displacement of the fender were obtained. It was confirmed that the longperiod motions, such as surging, swaying and yawing, were strongly affected by mooring system. By considering multi-directionality and frequency bandwidth of incident waves as input conditions for a numerical simulation, the calculation results of the vessel motions agree with the field observation data well.
\end{abstract}

Key Words : Moored vessel, long-period motion, field observation, numerical simulation

\section{1. はじめに}

近年，船舶の大型化に伴い，港内倸留船舶の長周 期動摇による荷役障害や倸留索切断等の事故が報告 され，大きな問題として取り上げられている. 現在, 係留船舶の動摇量の予測は数值シミュレーションに より行われているが，その精度は十分とはいえず, 動摇シミュレーションの予測精度を向上させるため には, 現地観測により係留船舶の長周期動摇の特性 を把握する必要がある.

松良ら（1994）1は，現地観測により港内外の波 浪場と係留船舶の動摇を観測し, 係留船舶の長周期 動摇の特性とその支配要因の解明を試みているが, ビデオ撮影により船体動摇の観測を行っているため に, 6 成分の船体重心位置での運動の評価はできな い. 港内係留船舶の動摇特性は, 各運動成分が係留 系を介して連成するため, 外力である波浪の特性を 把握するとともに, 6 成分の運動を同時に精度よく 観測した結果を用いて検討することが望ましい。

最近, 斉藤（1998） ${ }^{2)}$ は港内外の波浪場と GPS を 用いた船体動摇量の現地観測を行い，精度良く船体 動摇量を測定するとともに, 現地観測結果と動摇シ ミュレーション結果との比較も行っている. ただし,
斎藤（1998） ${ }^{2)}$ は動摇シミュレーションとして，代 表周波数に対する流体力係数を用いて運動方程式を 解く手法を採用している. 久保ら（1997） ${ }^{3)}$ が指摘 しているように, 代表周波数に対する流体力係数を 用いる方法では, 長周期動摇を十分な精度で評価す ることはできず，特に，波浪（短周期）成分の波が 作用した際に, 係留系の非線形性によって発生する 長周期動摇（サブハーモニックモーション）につい ては, 全く評価できない。波浪成分から長周期成分 まで精度よく動摇量を評価するためには, 現在のと

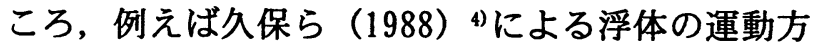
程式にメモリ一影響関数を用いて時系列的に解く方 法が最も実用的であると考えられる.

本研究では, 現地観測により港内外の波浪場と同 時に, 光波位置測定器と傾斜計を用いて, 港内係留 船舶の重心位置での 6 成分の動摇量を精度良く測定 すると共に, 係留索張力および防舷材変位の測定も 行い, 係留船舶の長周期動摇特性について検討を行 った. また，非線形性を考慮した波浪場の数値計算 により, 動摇シミュレーションの入力条件を評価し, 久保ら（1988） ${ }^{4)}$ の方法により, 動摇量および係留 索張力, 防舷材変位について現地観測結果との比較 を行った。 


\section{2. 現地調査の概要}

熊本県の最西端の天草下島に位置し, 東シナ海に 直接面している九州電力（株）苓北発電所専用港湾 において, 1996 年 2 月 23 日〜25 日および 1996 年 3 月 14 日〜3 月 17 日の期間に, 揚炭岸壁に係留さ れた石炭運搬船（約 69,000DWT）を対象に, 船体動 摇量, 係留索張力, 防舷材変位之港内外の水圧, 流 速および水位変動の連続観測を行った. 写真-1 に 船体係留状況（1996 年 2 月 23 日）を示す。また, 図-1 に港湾形状および波浪場の観測地点位置図を 示し, 表-1 に船体動摇量, 係留索張力, 防舷材変 位の観測装置一覧，図-2 に設置位置を示す。

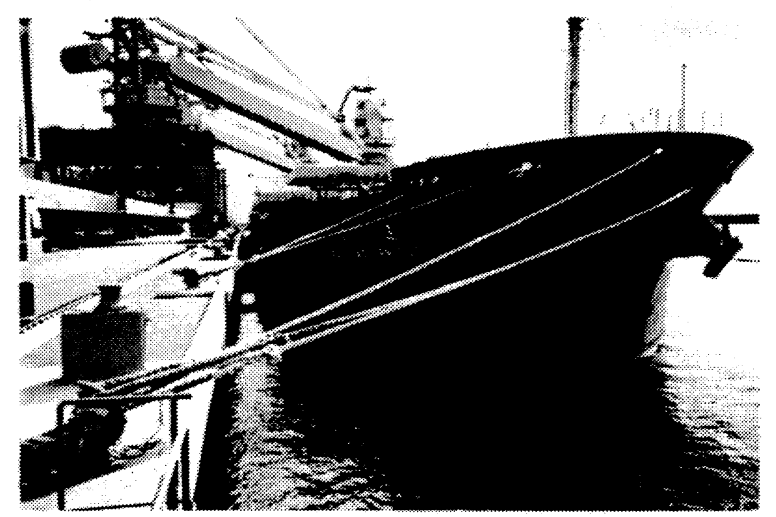

写真-1 船体係留状況

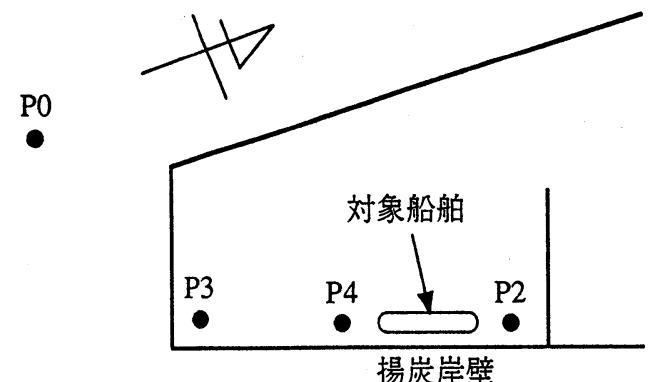

図-1＼cjkstart港湾形状と波浪観測地点位置図

表-1 船体動摇量等の観測装置一覧

\begin{tabular}{|c|c|c|c|}
\hline 計測項目 & 計測装置 & 装置名称 & 台数 \\
\hline \multirow{3}{*}{ 船体動摇量 } & 傾斜計 & SMM-1000 & 1 \\
\hline & 光波位置測定器 & ジオジメー夕 4400 & 2 \\
\hline & ビデオ装置 & 8mm ビデオ & 2 \\
\hline 係留索張力 & 鉄筋計 & $\mathrm{BF}-32 \mathrm{CT}$ & 2 \\
\hline 防舷材変位 & ワイヤー変位計 & DTP-2MDS & 2 \\
\hline \multirow[t]{2}{*}{ 波浪場 } & $\begin{array}{c}\text { 水圧センサー付 } \\
\text { 電磁流速計 } \\
\text { 招立波沖亭計 }\end{array}$ & $\begin{array}{l}\text { WAVE- } \\
\text { IIUNTER N }\end{array}$ & 4 \\
\hline & 超音波波高計 & SSW-II N & 2 \\
\hline
\end{tabular}

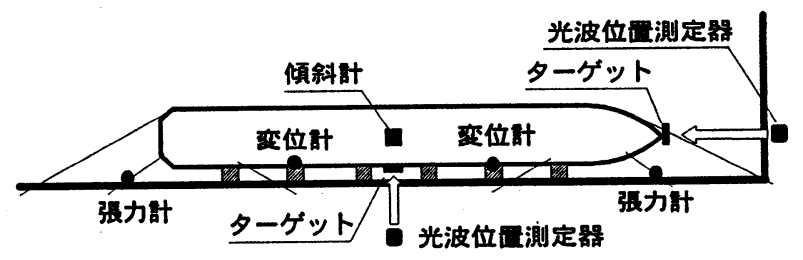

図-2＼cjkstart船体動摇量等の観測装置設置位置図
船体動摇量, 倸留索張力, 防舷材変位に関しては 昼間のみ 2 時間毎に 1 時間の連続観測を行った. 傾 斜計のデータは有線テレメータ, 光波位置測定器の データは無線テレメータ, 張力計および変位計のデ 一タは出カケーブルにより転送し, 観測室内のパソ コンに収録した. 傾斜計, 張力計, 変位計のサンプ リング間隔は 0.4 秒, 光波位置測定器のサンプリン グ間隔はターゲットを追いかけているために，0.4 秒以上の不等間隔になる. 光波位置測定器のデータ は, 線形補間により 0.4 秒の等間隔デー夕に変換し 解析に用いている. 光波位置測定器により観測され た船首および船舷のターゲットの 3 次元座標変位に は，船体回転運動成分の影響が含まれている，そこ で, 2 台の光波位置測定器のデータと傾斜計の rolling のデータを用いて, 船体重心位置での 6 成 分の船体動摇量を求めた.

港外 $\mathrm{P} 0$ 地点と港内 $\mathrm{P} 2, \mathrm{P} 3, \mathrm{P} 4$ 地点では, 水圧式 波高計および電磁流速計によりサンプリング間隔 1.0 秒で水圧変動と流速変動の連続観測を行い, P0 および P2 地点では, 超音波式波高計によりサンプ リング間隔 0.5 秒で水位変動の $20 \mathrm{~min} / 2 \mathrm{hr}$ の観測を 行った. $20 \mathrm{~min} / 2 \mathrm{hr}$ で観測した水位変動データを用 いて, 水圧変動から水位変動に変換するための補正 係数を求め, さらに, 潮位の除去を行った.

1 回目の観測期間（2 月 23 日〜2 月 25 日）は非 常に静穏な状況であり, 有意な船体動摇を観測でき なかったが，2 回目の観測期間（3 月 14 日〜3 月 17 日）には 3 月 15 日に観測地点付近を低気圧が通過 し，有意な船体動摇を観測した.

2 回目の観測期間中の係留船舶の船体諸元を表-2 に示す。.また，岸壁に設置されている防舷材は $\phi$ $1600 \mathrm{~mm}$ の定反力型防舷材であり, 2 回目の観測期間 中の係留船舶に用いられていた係留索は $\phi 70 \mathrm{~mm} の$ 繊維索であった. 係留状況の模式図を図-3に示す.

表-2 係留船舶の船体諸元

\begin{tabular}{|c|c|c|}
\hline 全長 & L (0. A. ) & $224.0 \mathrm{~m}$ \\
\hline 垂線間長 & L (B. P.) & $215.0 \mathrm{~m}$ \\
\hline 幅 & B (MLD) & $32.2 \mathrm{~m}$ \\
\hline 深さ & D (MLD) & $18.2 \mathrm{~m}$ \\
\hline 喫水 & Draft (MLD) & $13.27 \mathrm{~m}$ \\
\hline 重量トン & D. W. T. & $68,636 \mathrm{t}$ \\
\hline 総トン & G. T. & $36,074 \mathrm{t}$ \\
\hline 重心位置 & K. G. & $7.87 \mathrm{~m}$ \\
\hline 平均喫水 & M. D. & $8.12 \mathrm{~m}$ \\
\hline
\end{tabular}

K. G. およびM. D は 3 月 15 日 15 時の值

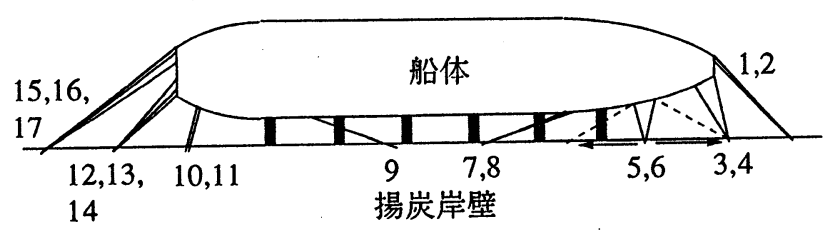

図-3 係留状況の模式図

(係留索 No. 5, 6 は 3 月 15 日 14 時に実線から破線のよ うに張り替えを行った。） 


\section{3. 現地観測結果}

\section{（1）波浪，船体動摇量の経時変化}

港外および港内の水位変動のスペクトル解析結果 より, 波浪成分（周期 16.7 秒以下）, サーフビート 成分 (周期 16.7 200 秒), 副振動成分（周期 200 秒以上）を定義し，水位変動および流速変動の時系 列を各成分に分離し，統計処理を行った。

図-4に, 2 回目の観測期間中の港内外の波浪成分 とサーフビート成分の有義波高および波向, 風向,

風速の経時変化を示す. 低気圧通過時（3 月 15 日） には，風速 $20 \mathrm{~m} / \mathrm{s}$ ，港外波浪成分有義波高 $3 \mathrm{~m}$ ，港外 サーフビート成分有義波高 $0.12 \mathrm{~m}$ を記録した．港外 と港内の波浪成分有義波高の最大となる時間にずれ が見られるが,これは風向の変化により風波が直接 港口から入ってきたことによるものと考えられる. また, 港外の波浪成分有義波高とサーフビート成分 有義波高の最大となる時間はほぼ一致しているが, 港外のサーフビート成分有義波高と港内のサーフビ 一ト成分有義波高の最大となる時間には，2～3 時 間程度のずれがある.これは，港内での共振により サーフビート成分が発達しているためであると考え られる.

図-5に 2 回目の観測期間中の船体動摇量の経時 変化を示す. 船体動摇量は最大で片振幅 surging 約 $0.9 \mathrm{~m}$, swaying 約 $0.5 \mathrm{~m}$ の有意な動摇が観測された. また, 係留索張力は最大で $112 \mathrm{kN}(11.4 \mathrm{tf})$, 防舷 材変位は最大で $0.172 m$ が観測された。

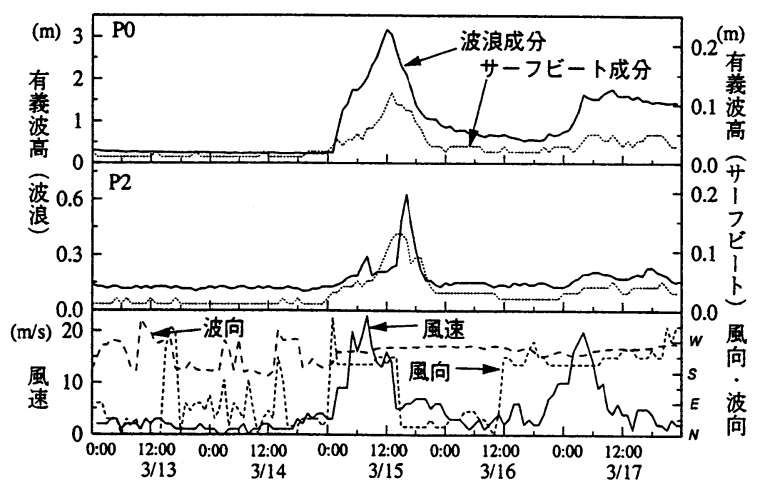

図-4 観測諸量の経時変化

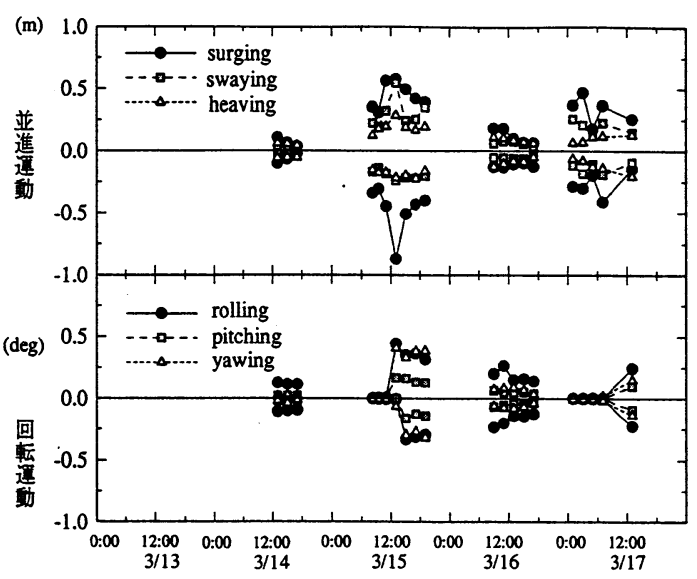

図-5 動摇量の片振幅の最大值の経時変化

\section{（2） 観測結果の時系列}

観測データの一例として, 3 月 15 日 15 時 20 分 からの 20 分の観測結果の時系列を示す. 図-6 は船 体重心位置での 6 成分の動摇量, 図-7 は船首およ び船尾側の係留索張力, 図-8 は船首および船尾側 の防舷材変位のものである.

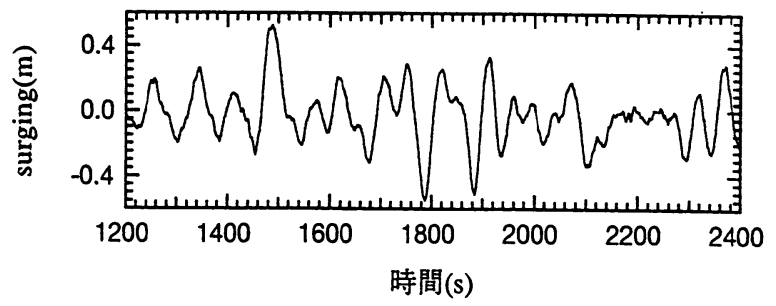

(a) surging

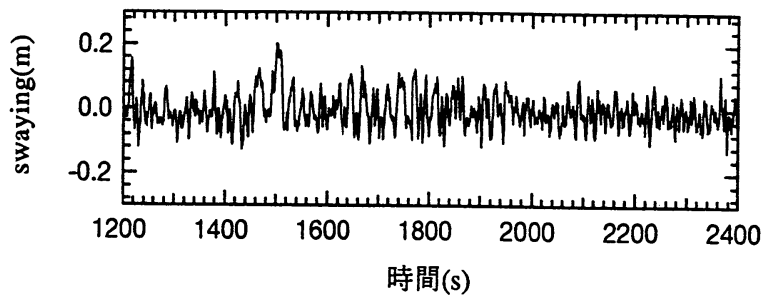

(b) swaying

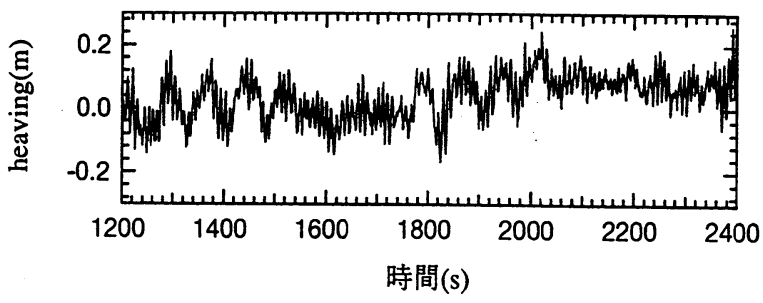

(c) heaving

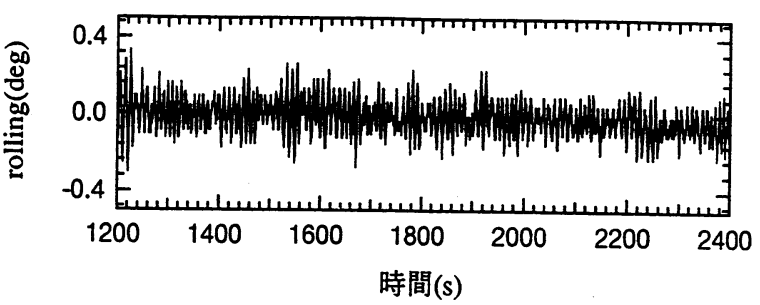

(d) rolling

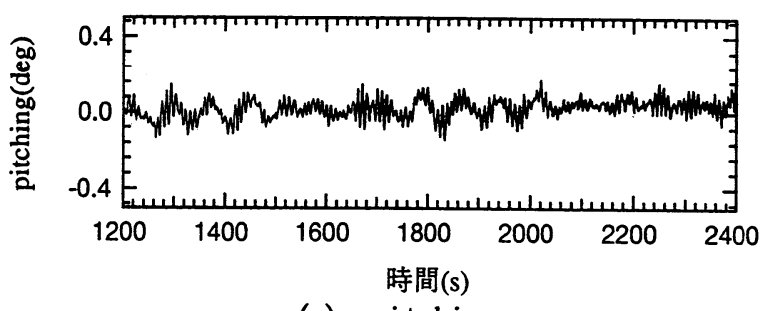

(e) pitching

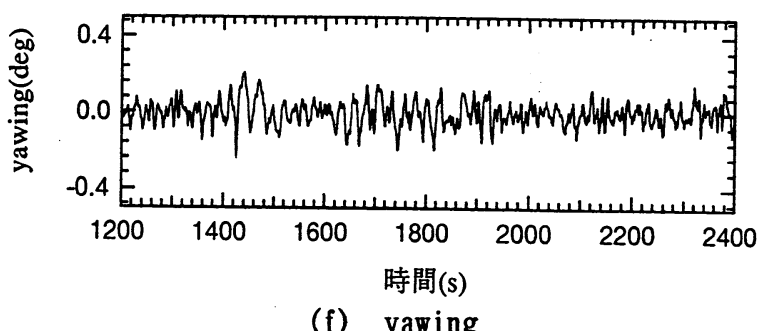

図-6 船体重心位置での 6 成分の動摇量 


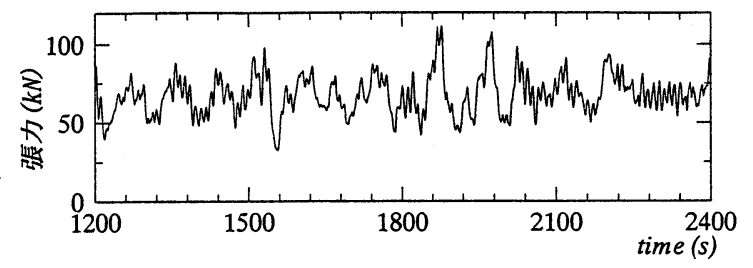

(a) 船首側

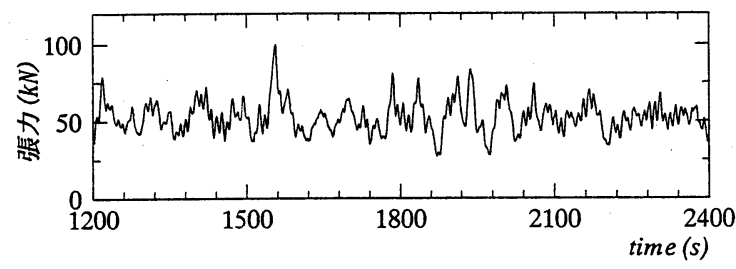

(b) 船尾側

図-7 係留索張力の観測結果の時系列

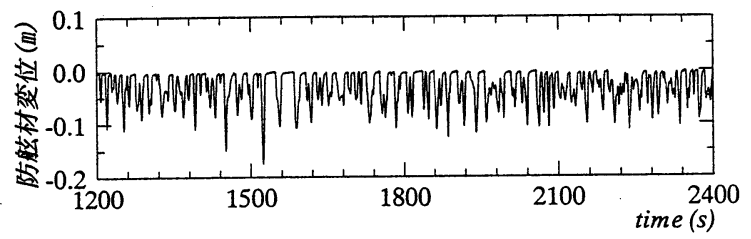

(a) 船首側

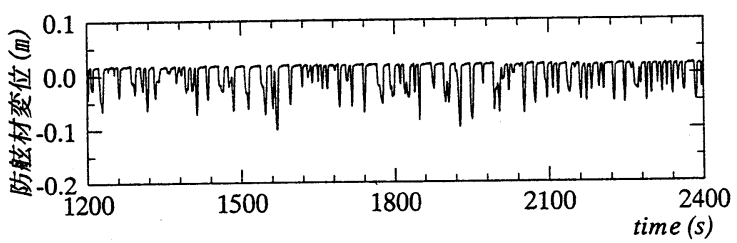

(b) 船尾側

図-8 防舷材変位の観測結果の時系列

\section{（3）周波数スペクトル特性}

動摇量が大きかった 3 月 15 日の 11 時, 13 時, 15 時, 17 時からの 1 時間デー夕を対象に, 周波数ス ペクトル特性について検討を行った. 港内 $\mathrm{P} 2$ 地点 の水位変動の周波数スペクトルを図-9 に示し, 図10〜15 に船体重心の 6 自由度運動成分の周波数ス ペクトル解析結果を示す. 残念ながら，13:00 のデ 一夕は, 船首側の光波位置測定器のデータおよび傾 斜計の yawing のデータが途中欠測になった. 欠測

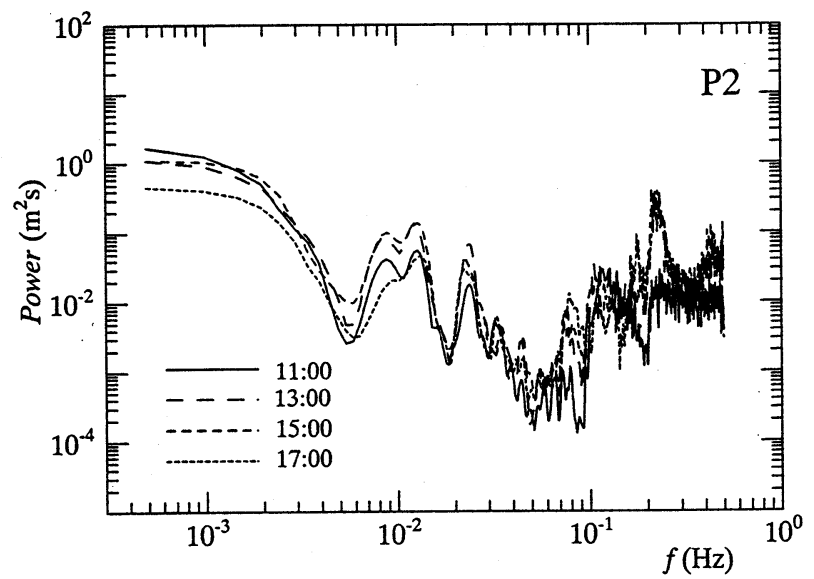

図-9 P2 地点の水位変動の周波数スペクトル

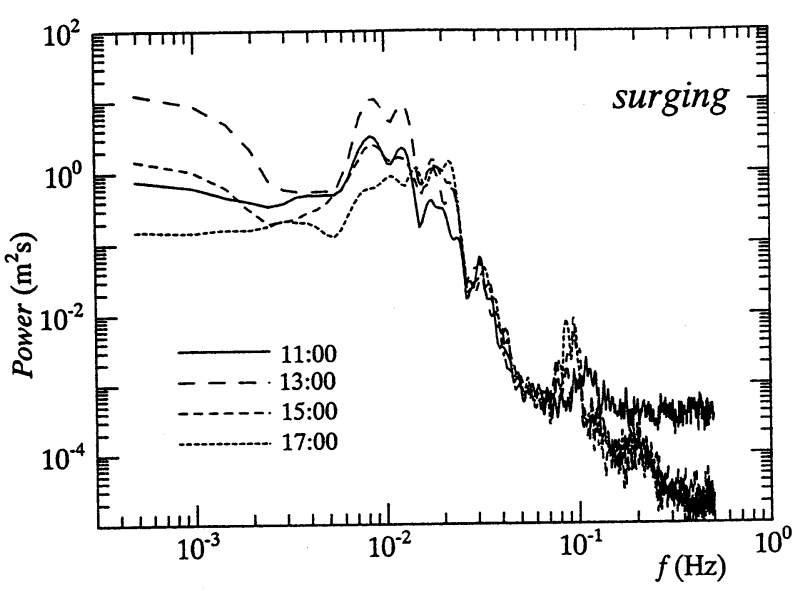

図-10 surging の周波数スペクトル

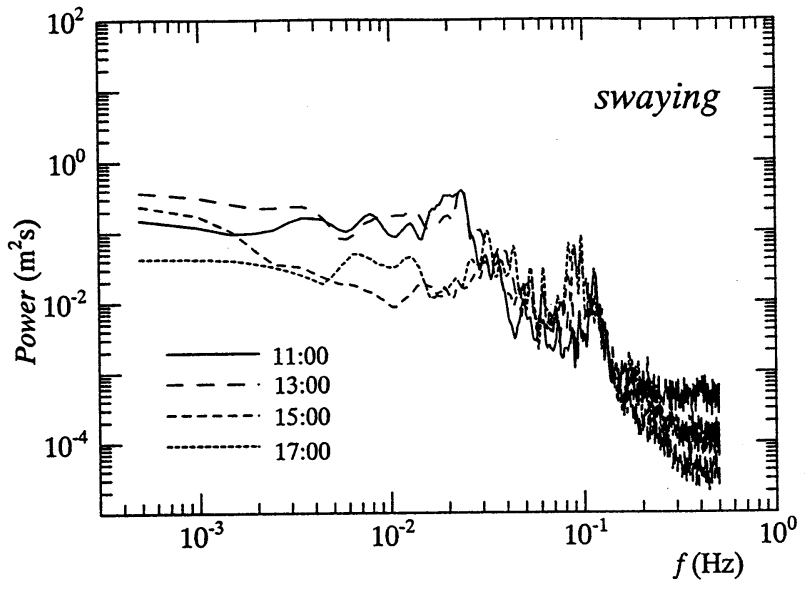

図-11 swaying の周波数スペクトル

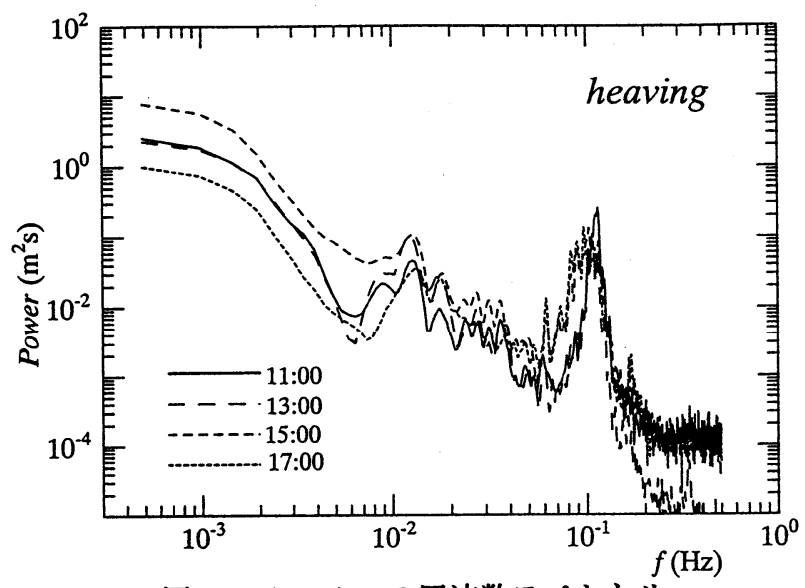

図-12 heaving の周波数スペクトル

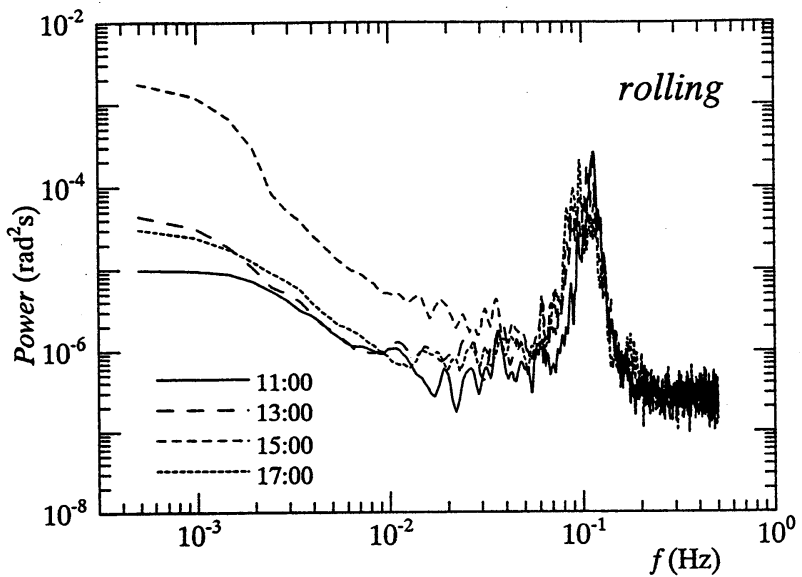

図-13 rolling の周波数スペクトル 


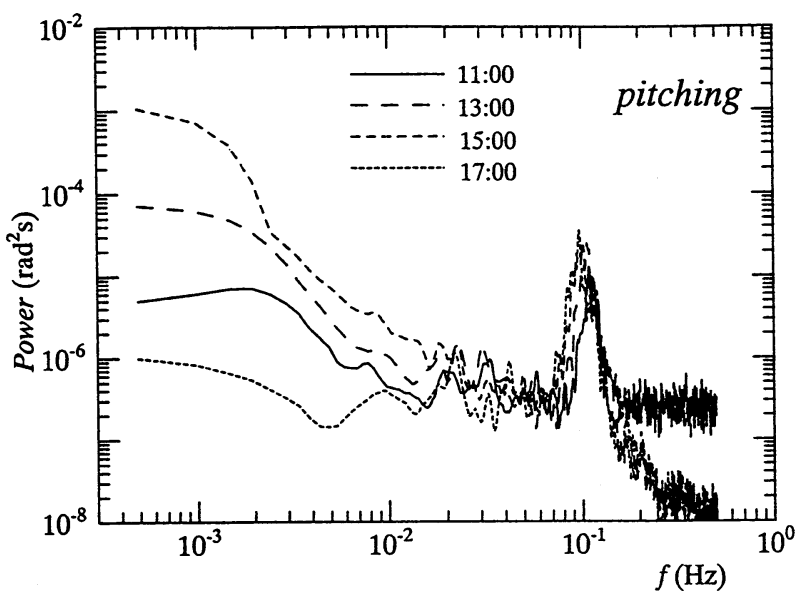

図-14 pitchingの周波数スペクトル

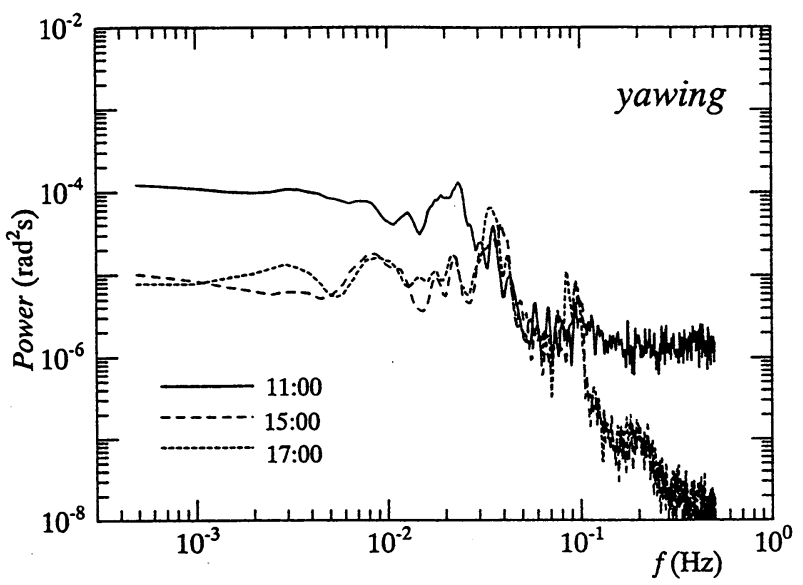

図-15 yawing の周波数スペクトル

期間を除去したデータで船体重心位置の並進運動成 分を計算し, 船舷側の光波位置測定器のデータとの 相関を取った結果, 非常に高い相関が見られたため, 13:00 の並進運動は船舷側の光波位置測定器のデー 夕, rolling および pitching は傾斜計のデータを 用いて解析を行った。

従来の研究結果と同様に, surging, swaying お よび yawing は長周期の動摇が顕著である.また, surging の周波数スペクトルは, 100 秒付近に二山 のピークが見られ，そのピークは P2 地点の水位変 動の周波数スペクトルに対応している. rolling と pitching は，短周期の動摇が顕著である. heaving の周波数スペクトルは, 10 秒付近と 100 秒付近に ピークが見られ，P2 地点の水位変動の周波数スぺ クトル形状と良い対応を示している.

観測期間中，船体動摇が大きくなったため，3 月 15 日 13 時 45 分〜14 時 45 分に係留索の張り替え作 業が行なわれた．表-3 に係留索の張り替え作業状 況を示し, 図-3 に係留索の張り替え状況を模式的 に示す.

係留索の張り替え前後（3 月 15 日 13 時と 15 時） で $\mathrm{P} 2$ 地点の水位変動の周波数スペクトルには, 大 きな変化は見られず（図-9，船体動摇の外力とな る波浪場はほぼ等しいと見なせることがわかる．係 留索の比較的緩い状態(3月15日 13時)では, surging および swaying の周波数スペクトル（図-12）を見
表-3 係留索の張り替え作業状況

\begin{tabular}{|l|l|}
\hline $13: 45 \sim 14: 15$ & $\begin{array}{l}\text { Tighten all head and spring } \\
\text { lines (No. } 1 \sim 4 \text { and } 7,8)\end{array}$ \\
\hline $13: 45 \sim 14: 15$ & $\begin{array}{l}\text { Two breas t lines transfer to head } \\
\text { and spring line (No. 5 and 6) }\end{array}$ \\
\hline $14: 20 \sim 14: 45$ & Tighten all stern lines (No. 9 14) \\
\hline
\end{tabular}

ると，長周期動摇が大きいが，係留索を張り換え， バネを固くした状態（3 月 15 日 15 時）では長周期 動摇が小さくなっている. 特に, swaying では, 係 留索を張り変え, バネが固くなったことにより, 広 い周波数帯にわたって, 動摇のエネルギーが減少し ていることがわかる. heaving, rolling, pitching については, 係留索の張り替え前後で, 周波数スぺ クトルの大きなな変化は見られない. また, 係留索 張力の最大値は, 係留索の張り替え前（3 月 15 日 13 時）は船首側 $91.1 \mathrm{kN}$, 船尾側 $91.6 \mathrm{kN}$ であったが, 倸留索の張り替え後(3 月 15 日 15 時)は船首側 $111 \mathrm{kN}$, 船尾側 $100 \mathrm{kN}$ となった. このことから係留船舶の長 周期動摇には, 係留索のバネ定数の影響が顕著に現 れ, バネを固くしたことで, 倸留索張力が大きくな ることが確認できた.

\section{4. 船体動摇シミュレーション}

動摇シミュレーションとして, 浮体の運動方程式 にメモリ一影響関数を用いて時系列的に解く方法 4) を採用し, 船体動摇量について現地観測結果之動摇 シミュレーション結果の比較を行った.

船体動摇量と港内の水位変動をスペクトルレベル で比較した結果, 船体動摇量と港内の水位変動は広 い周波数帯域で良い対応を示すことがわかった.よ って, 波浪成分から長周期成分まで精度よく動摇量 を評価するためには, 入力条件として波浪（短周期） 成分の波だけでなく, 長周期波も適切に評価する必 要がある. そこで, Boussinesq 方程式を用いて港 内波浪場の数值シミュレーション ${ }^{5)}$ を実施し, 船体 重心位置での長周期波の不規則性および多方向性を 評価することにより, 入力条件に波浪成分の波だけ でなく, 港内副振動の影響を考慮した長周期波も与 えた. 係留索の初期張力はウインチで巻いているも ののみ $39.2 \mathrm{kN}(4 \mathrm{tf})$ を与え, 外力としての風は, 観測時に得られた風速 $(5 \mathrm{~m} / \mathrm{s})$, 風向 (WSW) の変動 風を入力した. 以上により, 動摇シミュレーション による不確定要素は粘性減衰係数のみとなったと考 え, 粘性減衰係数のパラメタスタティを行った. そ の結果, 粘性減衰係数の值は, 従来の計算に用いら れてきた值 (surging 方向 0.4, swaying 方向 0.9) 4)より, やや小さく surging 方向 0.3 , swaying 方向 0.8 となった.

表-4 は 3 月 15 日 13 時の 6 成分の船体動摇量の 最大值に関して, 表-5 は係留索張力と防舷材変位 の最大值に関して, 現地観測結果と動摇シミュレー ション結果を比較したものであり, 動摇シミュレー ションによりほぼ十分な精度で予測可能なことがわ 
かる. 図-15 は surging, 図-16 は swaying の 3 月 15 日 13 時の動摇量の周波数スペクトルについて, 現地観測結果と動摇シミュレーション結果を比較し たものである.

周波数スペクトルレベルでも, 短周期成分, 長周 期成分ともに良い対応を示しており, 船体動摇シミ ユレーションにおいて, 入力条件に波浪成分の波だ けでなく, 港内副振動の影響を考慮した長周期波も 与えることにより, 十分な精度で現地観測結果を再 現できることを示した.

表-4 動摇量の最大值

\begin{tabular}{|c|c|c|c|c|c|c|}
\hline & \multicolumn{2}{|c|}{ Surging $(\mathrm{m})$} & \multicolumn{2}{|c|}{ swaying (m) } & \multicolumn{2}{|c|}{ heaving (m) } \\
\hline & $\max$ & $\min$ & $\max$ & $\min$ & $\max$ & $\min$ \\
\hline 実測 & 0.557 & -0.871 & .669 & -0.117 & 87 & .324 \\
\hline \multirow[t]{3}{*}{ 計算 } & 0.565 & -0.723 & 0.597 & -0.084 & 0.098 & -0.100 \\
\hline & \multicolumn{2}{|c|}{ rolling (deg) } & \multicolumn{2}{|c|}{ pitching (m) } & \multicolumn{2}{|c|}{ yawing (deg) } \\
\hline & $\max$ & $\min$ & $\max$ & $\min$ & $\mathrm{m}$ & $\min$ \\
\hline 実測 & 0.440 & -0.420 & 0.167 & -0.173 & 0.408 & -0.472 \\
\hline 計算 & 0.536 & -0.715 & 0.206 & -0.217 & 0.293 & -0.414 \\
\hline
\end{tabular}

表-5 係留索張力と防舷材変位の最大值

\begin{tabular}{|c|c|c|c|c|}
\hline \multirow{2}{*}{} & \multicolumn{2}{|c|}{ 係留索張力 $(\mathrm{kN})$} & \multicolumn{2}{c|}{ 防舷材変位 $(\mathrm{m})$} \\
\cline { 2 - 5 } & 船首側 & 船尾側 & 船首側 & 船尾側 \\
\hline 実測 & 91.1 & 91.6 & 0.129 & 0.103 \\
\hline 計算 & 106. & 89.6 & 0.156 & 0.118 \\
\hline
\end{tabular}

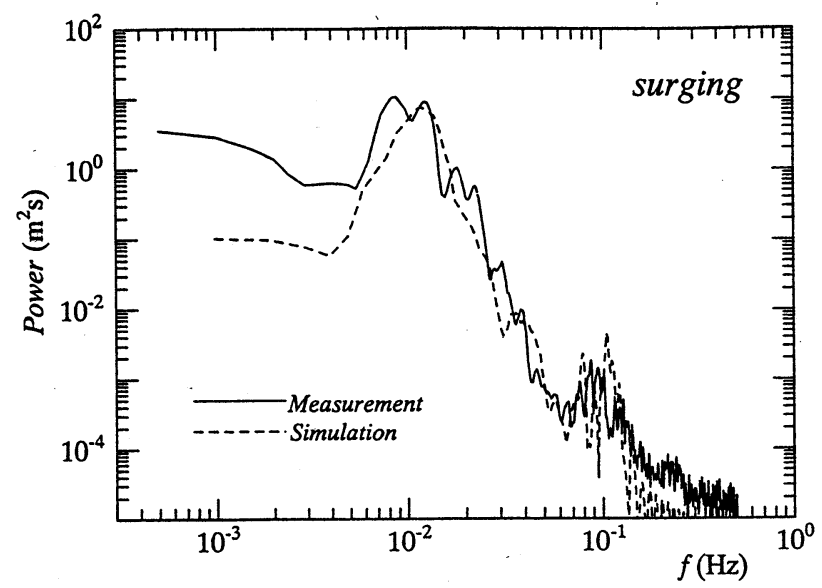

図-15 surging の周波数スペクトル

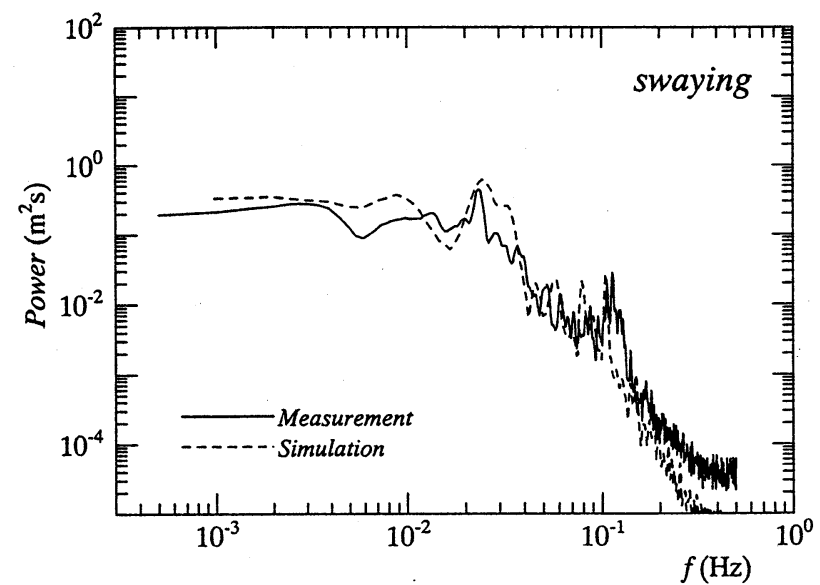

図-16 swaying の周波数スペクトル

\section{5. おわりに}

本研究により, 得られた結論をまとめると, 以下 のようになる.

(1)外力となる波浪の時系列データとともに, 数秒 から数十分までの広帯域の船体動摇の精度良い時系 列データが取得できた.

(2)surging および swaying は長周期の動摇が顕著 である. 特に, surging に関しては, 波浪観測結果 との相関から, 港内副振動（長周期波）が外力とな っていることが確認できた.

(3)係留索の比較的緩い状態では, surging および swaying の長周期動摇が大きかったが, 係留索を張 り換え, バネを固くした状態では長周期動摇が小さ くなった. このことから係留船舶の長周期動摇には, 係留索のバネ定数の影響が顕著に現れることが確認 できた.

(4)浮体の運動方程式にメモリ一影響関数を用いて 時系列的に解く動摇シミュレーション手法 ${ }^{4)}$ を採用 し, 入力条件に波浪（短周期）成分の波だけでなく, 港内副振動の影響を考慮した長周期波も与えること により, 現地観測結果を十分に再現できることを示 した.

謝辞 : 本研究を行うにあたり, 電力中央研究所我孫 子研究所水理部の池野正明主任研究員には, 数々の 有益な助言をいただいた.ここに, 記して感謝の意 を表す次第である.

\section{参考文献}

1）松良精三・渥美洋一・菅沼史典・宮本義憲 : 波群に 拘束された長周期波の港内における増幅特性と船体動摇 に関する現地観測, 海岸工学論文集, 第 41 巻, pp. 71-75, 1994.

2）斉藤直 : 三隅港の長周期波特性と船体動摇への影響 評価, 電力土木, pp. 87-91， 1999.

3）久保雅義・笹健児・白石悟・榊原繁樹 : 数值計算手 法が長周期波作用下における長周期船体動摇へ及ぼす影 響について, 海岸工学論文集, 第 44 巻, pp. 236-240, 1997. 4） 久保雅義 - 斉藤勝彦-下田直克 - 岡本俊策 : 岸壁前 面係留浮体の不規則波による船体動摇の時系列解析につ いて, 第 35 回海岸工学講演会論文集, pp. 687-691，1988. 5）藤畑定生・秦禎勝・森屋陽一・中山晋一・関本恒浩 : 現地観測による港内長周期波浪流速特性とその予測手法 に関する検討, 海岸工学論文集, 第 45 巻, pp. 306-310, 1998.

(1999. 4.19 受付) 